\title{
Demographic and Academic Outcomes of Freshman Attendees at Early and Late Orientation Sessions
}

by Denise L. Rode, Director of Orientation, Northern Illinois University

Is there a difference between new freshmen who attend sessions early in an orientation cycle versus those who attend late sessions? In my experience as orientation director at Northern Illinois University for more than 15 years, there seemed to be observable differences, both in the composition of the groups and in their academic outcomes after the first semester.

Early attendees appeared more often to be females than males, majority students rather than minority students, and more frequently majors in certain undergraduate colleges than others. Undeclared majors seemed to be over-represented in the later group of participants. Based on my observation of the greater responsiveness of early program attendees versus that of late attendees, I speculated that the groups also differed in academic performance and persistence during the first year.

This informal study reports attempts to verify my hunches about these two groups.

Northern Illinois University (NIU) is a comprehensive, public, residential four-year university of 25,000 students, approximately 18,000 of which are undergraduates. To serve its 3,000 entering freshmen and their families, the university offers more than 20 one-day orientation sessions (with concurrent family programs) in June, July, and August. Five hundred of these freshmen are admitted through a special program which provides a separate two-day orientation process.

For the 2,500 traditionally admitted students, program dates are assigned based on the time of admission to the university, although freshmen are able to request earlier or later orientation dates. This is the population on which this study is based.

To test my informal hypotheses, I gave the NIU Office of Institutional Research (IR) lists of freshmen attending the first orientation date of the 2002 freshman orientation cycle (June 10) $(\mathrm{N}=141)$ and those attending the last date (August 6) $(\mathrm{N}=152)$. At the completion of the Fall 2002 semester, IR analyzed the groups by gender, race/ethnicity, major department and major college, and pre-college academic characteristics (high school class percentile and ACT composite score). I also asked for data on enrollment status in NIU's elective, one-credit hour extended orientation course, UNIV 101: The University Experience. UNIV 101 is heavily promoted with new students and families at orientation sessions due to its high correlation with freshman academic success and persistence.

Several statistical tests were conducted to determine the differences between the groups of early and late orientation attendees. Chi-square analyses were performed to examine differences between the groups on gender breakdowns, UNIV 101 enrollment status, racial/ethnic group distribution, and academic college. In addition, t-tests were conducted to assess initial differences between the groups on ACT composite score and high school class percentile rank. 
Finally, three measures of academic performance were examined. Differences between the two groups on first semester grade point average (GPA) were analyzed using t-test procedures. Chi-square analyses were also conducted to examine differences between the two groups for second semester retention rate and the proportion of students who failed at least one course during their first fall semester.

Results are reported in the following areas:

\section{Gender Differences (Table 1)}

The overall gender distribution for the two groups was $52.6 \%$ male, $47.4 \%$ female. For the earliest orientation participants, $49.6 \%$ were male and $50.4 \%$ were female; for the latest freshman orientation group, 55.3\% were male and $44.7 \%$ were female. Although women were slightly in the majority of the early attendees, the difference was not statistically significant.

\section{TABLE 1}

Earlier Orientation and Later Orientation Fall 2002 New Freshmen By Gender

\begin{tabular}{lcccccr} 
& $\begin{array}{c}\text { Early } \\
\text { Orientation }\end{array}$ & $\%$ & Orientation & $\boldsymbol{\%}$ & Total & $\%$ \\
\hline Male & 70 & $49.6 \%$ & 84 & $55.3 \%$ & 154 & $52.6 \%$ \\
Female & 71 & $50.4 \%$ & 68 & $44.7 \%$ & 139 & $47.4 \%$ \\
Total & 141 & $100.0 \%$ & 152 & $100.0 \%$ & 293 & $100.0 \%$
\end{tabular}

Note: Traditional admission students who completed the first semester were included in the analysis. $x^{2}=0.926, d f=1, p>.05$

\section{Extended Orientation Course (UNIV 101) Enrollment Differences (Table 2)}

For the two groups combined, $25.3 \%$ of the students enrolled in the UNIV 101 course and $74.7 \%$ did not enroll. Early attendees were much more likely to enroll for the course (39\%) than were late orientation attendees $(12.5 \%)$. Part of the reason for this pattern was due to the fact that many UNIV 101 sections were filled by the time of late orientation. 
Earlier Orientation and Later Orientation Fall 2002 New Freshmen By UNIV 101 Course Enrollment Status

\begin{tabular}{lcccccc} 
& $\begin{array}{c}\text { Early } \\
\text { Orientation }\end{array}$ & $\boldsymbol{\%}$ & $\begin{array}{c}\text { Later } \\
\text { Orientation }\end{array}$ & $\boldsymbol{\%}$ & Total & $\%$ \\
\hline UNIV 101 & 55 & $39.0 \%$ & 19 & $12.5 \%$ & 74 & $25.3 \%$ \\
Non-UNIV 101 & 86 & $61.0 \%$ & 133 & $87.5 \%$ & 219 & $74.7 \%$ \\
Total & 141 & $100.0 \%$ & 152 & $100.0 \%$ & 293 & $100.0 \%$
\end{tabular}

Note: Traditional admission students who completed the first semester were included in the analysis.

$x^{2}=27.226, d f=1, p<.001$

Racial/Ethnic Differences (Table 3)

Statistically significant differences were demonstrated when the groups were analyzed by race/ethnicity. For both groups combined, $11.3 \%$ of the students identified themselves as African American, 5.8\% as Asian, 7.2\% as Hispanic, 73.7\% as white, and $2 \%$ as missing or other.

For the first-day attendees, African American freshmen represented 2.1\% of the total; Asian freshmen were 5\% of the total; Hispanic freshmen, 3.5\%; white, $87.2 \%$; and other, $2.1 \%$. On the last orientation date, $19.7 \%$ were African American, $6.6 \%$ were Asian, $10.5 \%$ were Hispanic, $61.2 \%$ were white, and $2 \%$ were other. These data verified the perception that the orientation groups were more diverse in terms of race and ethnicity as the program cycle progressed.

\section{TABLE 3}

Earlier Orientation and Later Orientation Fall 2002 New Freshmen By Race/Ethnicity

\begin{tabular}{lcccccc} 
& $\begin{array}{c}\text { Early } \\
\text { Orientation }\end{array}$ & $\%$ & $\begin{array}{c}\text { Later } \\
\text { Orientation }\end{array}$ & $\boldsymbol{\%}$ & Total & \% \\
\hline African American & 3 & $2.1 \%$ & 30 & $19.7 \%$ & 33 & $11.3 \%$ \\
Asian & 7 & $5.0 \%$ & 10 & $6.6 \%$ & 17 & $5.8 \%$ \\
Hispanic & 5 & $3.5 \%$ & 16 & $10.5 \%$ & 21 & $7.2 \%$ \\
White & 123 & $87.2 \%$ & 93 & $61.2 \%$ & 216 & $73.7 \%$ \\
Missing/Other & 3 & $2.1 \%$ & 3 & $2.0 \%$ & 6 & $2.0 \%$ \\
Total & 141 & $100.0 \%$ & 152 & $100.0 \%$ & 293 & $100.0 \%$
\end{tabular}

Note: Traditional admission students who completed the first semester were included in the analysis. $x^{2}=32.181, d f=4, p<.001$ 


\section{Academic College Differences (Table 4)}

NIU has six academic colleges which grant undergraduate degrees. The largest of these is the College of Liberal Arts and Sciences (CLAS), which includes majors in 17 departments and, at the time of the study, most of the university's undeclared majors. It has been my observation over many years that CLAS students tend to participate in Orientation later than students in other colleges. The results of this study verified that assumption for CLAS students and for students in one of the smaller colleges. It also has been my perception that students in the Colleges of Business, Education, and Health and Human Sciences tend to participate early.

For the two dates combined, College of Business students made up 21.8\% of the group. Education students represented 9.2\%, Engineering and Engineering Technology students were $9.6 \%$ of the total, Health and Human Sciences students were 8.2\%, Liberal Arts and Sciences were 44\%, and Visual and Performing Arts students were 7.2\%.

Among the first date attendees the percentages were as follows: Business, 25.5\%; Education, 12.8\%; Engineering, 12.8\%, Health and Human Sciences, 9.2\%; Liberal Arts and Sciences, 34\%; and Visual and Performing Arts, 5.7\%.

For the last freshman orientation date, Business freshmen represented $18.4 \%$ of the total; Education students, 5.9\%; Engineering, 6.6\%; Health and Human Sciences, 7.2\%; Liberal Arts and Sciences, 53.3\%; and Visual and Performing Arts, 8.6\%.

This analysis confirmed my hunch about CLAS, Business, and Education students but did not support my assumption for Health and Human Sciences students.

\section{TABLE 4}

\section{Earlier Orientation and Later Orientation Fall 2002 New Freshmen By College}

\begin{tabular}{lcccccc} 
& $\begin{array}{c}\text { Early } \\
\text { Orientation }\end{array}$ & $\%$ & $\begin{array}{c}\text { Later } \\
\text { Orientation }\end{array}$ & $\%$ & Total & \% \\
\hline Business & 36 & $25.5 \%$ & 28 & $18.4 \%$ & 64 & $21.8 \%$ \\
Education & 18 & $12.8 \%$ & 9 & $5.9 \%$ & 27 & $9.2 \%$ \\
Eng. \& Eng. Tech & 18 & $12.8 \%$ & 10 & $6.6 \%$ & 28 & $9.6 \%$ \\
Health \& Human & 13 & $9.2 \%$ & 11 & $7.2 \%$ & 24 & $8.2 \%$ \\
Sciences & & & & & & \\
Liberal Arts \& & 48 & $34.0 \%$ & 81 & $53.3 \%$ & 129 & $44.0 \%$ \\
Sciences & & $5.7 \%$ & 13 & $8.6 \%$ & 21 & $7.2 \%$ \\
Visual \& & 8 & & & & & \\
Performing Arts & & $100.0 \%$ & 152 & $100.0 \%$ & 293 & $100.0 \%$ \\
Total & 141 & &
\end{tabular}

Note: Traditional admission students who completed the first semester were included in the analysis. $x^{2}=15.694, d f=5, p<.01$ 


\section{Academic Outcome Differences (Table 5)}

Of greatest interest to me (and other administrators on my campus) were the data which compared early orientation participants with late attendees in terms of their academic performance and persistence after the first semester. Comparing the two groups in terms of pre-college characteristics, they differed only slightly in ACT composite score (23.7 for early attendees versus 23.0 for late attendees), but significantly for high school class percentile $(69.4 \%$ for early attendees versus $62.3 \%$ for late attendees).

Performance and persistence data after the first semester were striking. With respect to retention, the earlier orientation group showed a second semester retention rate of $97.2 \%$ while the later orientation group had a retention rate of $88.8 \%$; this difference was significant $\left(\mathrm{x}^{2}(1)=7.66, \mathrm{p}<.01\right)$. Considering first semester GPA, the earlier orientation group had an average GPA of 2.865 as compared with the an average GPA of 2.094 for the later orientation group; this difference was also significant $(+(277)=3.243, \mathrm{p}<.01)$. Finally, the percentage of students in each group who had failed at least three credit hours during the first semester was compared. For the earlier orientation group, $10.6 \%$ failed at least one course while $41.5 \%$ of the later group failed at least one three-credit hour course; this difference was significant $\left(\mathrm{x}^{2}(1)=35.54, \mathrm{p}<.01\right)$.

\section{TABLE 5}

\section{Mean High School Percentile, ACT, and Academic Outcome Measures for Earlier Orientation and Later Orientation Fall 2002 New Freshmen}

\begin{tabular}{lccccc} 
& $\begin{array}{c}\text { Early } \\
\text { Orientation }\end{array}$ & $\begin{array}{c}\text { Later } \\
\text { Orientation }\end{array}$ & $\boldsymbol{d} f$ & $\boldsymbol{t}$ & $\boldsymbol{x}^{2}$ \\
\hline High School Class Percentile & 69.4 & 62.3 & 277 & $3.24^{* *}$ & - \\
ACT Composite & 23.7 & 23.0 & 285 & $2.20^{*}$ & - \\
First Semester GPA & 2.885 & 2.094 & 291 & $8.00^{* *}$ & - \\
Second Semester Retention Rate $^{\mathrm{a}}$ & $97.2 \%$ & $88.8 \%$ & 1 & - & $7.66^{* *}$ \\
Proportion With Failed Grades $^{\mathrm{a}}$ & $10.6 \%$ & $41.5 \%$ & 1 & - & $35.54^{* *}$
\end{tabular}

Note: Traditional admission students who completed the first semester were included in the analysis. a Having failed grades of at least three credit hours.

$* * p<.01$

$* p<.05$ 


\section{Conclusions}

Based on the above findings, I concluded the following:

*There are significant differences between those who come to NIU's freshman orientation programs early in the cycle and those who attend the late programs. Although significant differences cannot be seen by gender, the composition of the group that attends later is much more diverse in other ways, and program content and approaches must consider those differences.

*Those who attend early programs may have a relatively strong support system of parents, siblings, friends, counselors, and/or teachers. This support system probably has assisted these students in pre-college activities such as applying for admission, applying for financial aid, and sending in orientation reservations and housing deposits. Furthermore, these students may come from backgrounds that know about and encourage early action in these areas. It would be helpful to know the percentages of first-generation students in the early and late groups, which might help to explain the differences.

*Late orientation attendees may be in greater need of support services such as financial aid, tutoring, mentoring, time management strategies, and study skills assistance. They also may benefit more from extended orientation courses, such as Northern's UNIV 101: The University Experience, which builds in support from faculty/staff instructors, Peer Instructors, and other first-year students. Efforts must be made to ensure that ample space is available in such courses for late orientation participants. Greater emphasis on proven resources, retention efforts, and success strategies also should be given during late orientation sessions.

*It is likely that family members participating with their students in late orientation programs may be unfamiliar with the structure and expectations of colleges and universities. The content and emphases of late family orientation programs should be reviewed and revised as necessary to educate parents and other family members about differences between high school and college academic programs and expectations.

*According to the retention literature (Cuseo, 2002, p. 2; Kuh, Schuh, Whitt, \& Associates, 1991, p. 8; Lotkowski, Robbins, \& Noeth, 2004, pp.4, 6, 7, 9 ,11; Tinto, 1993, pp. 46-47, 205), level of commitment to both the college or university and to a major or career makes a difference in a student's persistence to graduation. It is likely that freshmen who attend early orientation sessions have a greater commitment to, as well as greater knowledge about, the institution, leading them to be among the first participants. Conversely, late participants may lack a firm commitment to the school and/or to a major program. Orientation activities might be tailored to increase affiliation with the institution and to emphasize the campus's career development resources.

*Although it might be tempting to conclude that late orientation participants are more challenging to work with than early attendees, this may in fact not be the case. Some early participants may be overconfident in their ability to navigate the higher education experience and may believe they have little to gain from orientation programs. 
They also may have parents or other family members who are over-involved in their college decisions and, for example, may insist on being part of the student's advising session and/or registration process, which may run counter to the institution's philosophy.

On the other hand, late participants and their families may be refreshingly receptive to the orientation staff's efforts to inform and encourage them in this new venture. Certainly, late participants need and deserve as much attention, if not more, from orientation professionals.

\section{Implications for Practice}

How has my work with new students and their families changed as a result of knowing more about the nature of early and late orientation attendees? First and foremost, I have discarded the notion of a "one size fits all" approach to Orientation. Rather than assuming that students and their families need to hear a uniform message throughout the summer, I tailor the program as the cycle progresses to an audience that may be less familiar with and committed to higher education.

In the opening remarks at Orientation, the importance of personal responsibility and effort is stressed. This message receives greater emphasis as the summer progresses. Given that the ACT composite scores of early and late participants are nearly equal, it can be inferred that there may not be a great difference in innate academic ability between the two groups. The fact that the early group as a whole has a significantly higher class rank than the late group may attest to a higher level of initiative and self-motivation, leading to higher academic achievement both in high school and later in college.

As the NIU orientation cycle progresses, faculty presenters and orientation leaders are asked to speak to students and parents more directly about how academic life and expectations are different at the college level than in high school and about the importance of taking personal responsibility and initiative to be academically successful. In working with our family program, I attempt to tactfully share what I've learned about the academic performance of students who attend late orientation without unduly alarming family members. I strongly encourage students to avail themselves of campus resources that can help them succeed, and I familiarize family members with those resources so that they can urge their students to use them during the first year, if needed. Part of this effort involves directing family members to printed and Web-based resources contained in the Family Handbook, to which they can refer in the future.

Toward the end of the cycle when more "undecided" students attend, we promote the university's career planning course as well as career development services provided by Career Services, academic advising units, and other counseling agencies. Academic support services such as tutoring and Supplemental Instruction programs are identified. As a means of providing additional support to our increasingly diverse freshman class, we also invite staff from other units such as Retention Programs, the Center for Black Studies, and the Latino Resource Center to meet with new students and their families in 
seminars, over lunch, and before and after the daily programs.

Course availability is frequently an issue on our campus at late orientation, and historically, late orientation participants have had to register for whatever courses might be left after other students have registered. At NIU, we have had some success in reserving course seats or adding sections of high-demand courses needed for lateattending students so that they have not been significantly disadvantaged. We also have learned to reserve some seats and/or sections in UNIV 101 for these students, who may benefit from the course more than the earlier students do.

The results of this informal study have to some extent "changed the way we do business" with Northern's late orientation freshman participants. More scientific study is needed to extend what we know about the differences in our freshman class. A next step is to expand this research to include the first week and last week of orientation participants. It also would help us serve our freshmen better to learn what percentages of each group represent first-generation students.

This study is confined to one large, comprehensive, public institution. Before generalizing the findings to other colleges and universities, it is recommended that the study be replicated on other campuses.

Finally, it is important to keep in mind that we ought not overgeneralize our findings. There certainly are early orientation attendees who will not succeed academically and who will not be retained in college. Conversely, there will be late orientation attendees who will succeed and graduate against all odds (this author being one of them many years ago). However, we can use what we know generally about orientation attendance patterns to enhance the ways in which we serve the first-year students to maximize their opportunities for academic and personal development and success.

\section{References}

Cuseo, J. (2002, February). Paper presented at the concurrent session, Student retention: The big picture. Annual Conference on the First-Year Experience, Orlando, FL.

Kuh, G. D., Schuh, J. H., Whitt, E. J., and Associates. (1991). Involving colleges: Successful approaches to fostering student learning and development outside the classroom. San Francisco: Jossey-Bass Publishers.

Lotkowski, V. A., Robbins, S. B., \& Noeth, R. J. (2004). The role of academic and non-academic factors in improving college retention (ACT Policy Report).

Retrieved February 25, 2005, from http://www.act.org/research/policy/pdf/college_retention.pdf

Tinto, V. (1993). Leaving college: Rethinking the causes and cures of student attrition (2nd ed.). Chicago: The University of Chicago Press.

The author gratefully acknowledges the invaluable assistance of J. Daniel House and Beiling Xiao of the NIU Office of Institutional Research in the development of this article. 